\title{
Office Interiors and the Fantasy of Information Work
}

\author{
Renyi Hong \\ University of Southern California, Annenberg School for Communication and \\ Journalism, California, United States, renyihon@usc.edu
}

\begin{abstract}
This essay provides a historical context to the office interior, describing its capacity to enchant the sphere of work and to influence the conception of an information worker. Focusing on Florence Knoll and Robert Propst, American designers who contributed to the modern aesthetic in the mid-twentieth century, I highlight how the sale of offices convey an idea of information work which is compatible with pleasure, and how these ideas relate to middle-class norms. Knoll and Propst had relied heavily on the promotional techniques of showrooms, textiles, seminars, and informational materials. These communicative practices emphasise the sensate quality of information work, which coach workers to recognise and interpret the visual, aural, and tactile quality of work environments. In doing so, it also ties sensations of pleasure to the prospect of self-transformation and the fantasy of class mobility.
\end{abstract}

Keywords: Office, Neoliberal Subjectivity, Affective Labour, History, Critical Design, Corporate Space, Affect Theory

Acknowledgement: I would like to thank the reviewers for their patience and feedback with this essay. I am also thankful to Barbara Hahn, Jinny Koh, Sarah Banet-Weiser, Tisha Dejmanee, and Zhang Lin for their inputs.

\section{Introduction}

Change Your Space, Change Your Culture, a management trade book published in 2014, makes the case that the office should be a place of refuge, a "safe place that offers some relief, hope, meaning, and accomplishment" from the "external jungle", the world outside the office which is stressful and replete with unhappy situations (Miller, Casey and Konchar 2014, 18). Most workers, the authors write, are worn out by the ordinary demands of everyday life: the long commutes, economic uncertainty, medical problems, and relational strife. This forces them to operate on the "raw edge of life", wearing on their affective states, and inhibiting their performance at work. As a result, corporations have a vested interest to build therapeutic workspaces that can serve as a bulwark against negativity. A space designed to feel like "home", they offer, will ensure that employees can realise their best selves, and become the engaged, creative, inspired, hardworking employees that companies yearn for (Ibid., 195).

Today, offices of companies like Google, Facebook, TBWAIChiatlDay, and coworking spaces like WeWork and Neuehaus, manifest how corporate space has become a prominent aspect of management discourse. In this discourse, beautified surroundings do not only provide companies with a means of cultivating the best selves of workers, they also facilitate the development of what Kuehn and Corrigan 
$(2013,17)$ have called "hope labor," a condition where individuals draw "from the attractive conditions of the present" in order to project their "desires into the future."

This logic can be seen operating in the motto of the coworking giant WeWork, which argues that chic workplace environments can help users "do what [they] love." As a WeWork member relates in a PBS news coverage, WeWork has "really discovered the secret sauce on how to make this place feel hip, feel new, feel innovative. Having guests come into this environment actually adds a real sense of, hey, we're a larger company than we actually are" (Solman 2015). Here, aesthetic pleasure is made synonymous with the real potential for success. WeWork prides itself on democratising the "nice" offices of "cool tech companies like Google", suggesting also that that more can have a chance at fulfilling their dreams as hip workplaces become publically available (Agence France-Presse 2016).

The arguments of WeWork are seductive, but they conceal the economic realities of many who inhabit its space. Most who pay to work in WeWork - upward of $\$ 350$ a month - are not Google employees, but freelancers and entrepreneurs, vulnerable workers who are subject to the precarity of markets (Andrejevic 2012, Duffy 2015, Hearn 2008, Neff 2012). As Cohen (2012) points out, many freelancers are not freelancing by choice: they are forced into self-employment because of the costcutting measures of corporations. And though freelancers may have more flexibility with how their time is structured, they are also subject to the vagaries of the economy and the transient nature of gigs. These realities were made especially evident during the Great Recession. 79\% of freelancers surveyed in 2010 by the Freelancers Union reported having insufficient work for the year, and many had to dip into their savings or chalk up debt to make ends meet (Horowitz and Poynter 2012).

From this perspective, corporate spaces may be understood as an intervention into the problems of post-Fordist labour. The spacious lounges, sleek desks, fair trade coffee, and calming ambient music provided by the WeWork workplace may help blunt the anxieties of precarity, cultivating the psychologies which enable workers to realise their labouring potentials despite difficult conditions. Correspondingly, this allows the paradigmatic affective state of the neoliberal present to shift - at least partially - from what Virno (1996) describes as "disenchantment" to a state of renewed excitement, hope, and ease.

This essay examines this trend historically, seeking to understand the link between office design and the affective quality of information work so as to illuminate our contemporary attachment to office space. My goal is twofold: first, I aim to show how the modern office aesthetic, developed at the turn of the mid-twentieth century, envisioned a different kind of personhood for the information worker of the New Economy. The information worker, Hardt and Negri (2004) explain, is a worker who deals with immaterial processes and products, and whose labouring potentials depend more on characteristics of cognitive intelligence, communicativeness, and affectivity. Examining the sales techniques of two of the most influential early American designers of modern, mass-produced corporate interiors from the late 1940 s to the late 1960s, Florence Knoll and Robert Propst, I explain how their designs have both influenced and reflected the qualities expected of this modern information worker, and the politics involved in this process.

Although the idea of an "information worker" might seem self-evident today, its meaning was subject to various contentions in the twentieth century, when offices were populated by people of a wide range of hierarchies and professions, and consequently, class, gender, and race positions (Murphy 2006). Workers - including 
secretaries, middle-managers, clerks, and executives - often operated in close quarters within the same office building. In this setting, Knoll and Propsts' designs had the effect of providing a middle-class definition to this broad idea of an "information worker". Workers for whom they designed the workplace were valued for their cognitive abilities, and their labouring potentialities were compatible with the feelings of aesthetic pleasure. Given that this model of an information worker was likely to be middle-class, male, and white, the values built into their design also gave information work an aura of middle-class respectability (Ibid.).

Through this logic, both Knoll and Propst introduced a post-Fordist ethos to information work. Expressing that dull, dreary workplaces could inhibit the cognitive performance of workers, Knoll and Propst argued for modern designs on the grounds that an aesthetically pleasing office would make employees more energetic, creative, collaborative, emotionally intelligent, and ultimately, capable of providing more value to the corporations they serve. Their views of information work fused pleasure and labour; those who found pleasure in their labour were also likely to be the best workers. The modern office interiors designed by Knoll and Propst, therefore, introduced a fantasy of how information work could and should feel.

However, the relationship between aesthetics, pleasure, and subjectivity is not to be taken for granted as transparent or natural. Indeed, both Knoll and Propst initially had trouble convincing American consumers of the ideas behind their designs because the aesthetic was read as too radical. Consumers had difficulty understanding what these expensive designs hoped to accomplish. Thus my second intent is to describe how Knoll and Propst individually weaved and constructed the cultural meaning around their designs through the promotional techniques of showrooms, textiles, seminars, and informational materials. This focuses on what Lefebvre (1991 [1974]) has called "conceptualized space" or "representations of space", the ways in which architects, planners, artists, and designers have influenced the interpretative framework of space.

To be sure, Knoll and Propst were not the only influential mid-twentieth designers of corporate interiors. There are others who contributed significantly, such as Charles and Ray Eames, and George Nelson. Thus, this essay does not claim to be a comprehensive historical review of modern office interiors or its designers. Nonetheless, both Knoll and Propst were recognised for having an important influence on commercial office interiors. Knoll was one of the first professional office interior designers, and an important figure in the eventual mainstreaming of the modern aesthetic. Propst was the inventor of the now ubiquitous modular office cubicles, and his attention to the science of work and its relationship to space continues to be a hallmark of the Herman Miller brand where he worked. Therefore examining their methods of promotion provides us with an important, if necessarily fragmented, perception of how we came to understand the relationship between workspaces and information work.

This essay proceeds by providing a historical backdrop to the rise of the modern aesthetic, explaining the dominant appearance and concerns of workplaces in prior periods. I subsequently offer the theoretical framework for my analysis of the promotional efforts of Knoll and Propst. Following an analysis of the promotional techniques, I bring the essay to a close by highlighting the historical links between these early ideologies of design and contemporary workspaces. 


\section{From the Bullpen to the Modern Office}

Back in 1964, Elaine Kendall of the New York Times Magazine had observed a new trend. "No one just wants a place to work anymore", she writes: offices were being beautified so much that "the home is beginning to seem quite substandard in comparison with the sumptuous new offices" (59-60). Kendall's observation is indicative of a shift in the perception of office spaces that took place in the turn of the mid-twentieth century, where corporations and employees begun to attend to the aesthetics of their workspace, believing that its appearance had a direct impact on their work performance.

To understand the novelty of this trend, it is necessary to note the difference in office appearance prior to the Second World War. Before the war, offices were typically organised through Taylorist principles, with similar desks and cabinets arranged in functional rows so that paperwork could move in predictable patterns with minimal loss of time. These layouts, also colloquially called bullpens, attended more to efficiency than to workers' comfort. Workers were seated in an open area, with other workers to their sides, front and back so that paperwork could easily be passed around. The repeating rows of identical desks and chairs were painted in dull colours, and like schoolrooms, workers were made to face the front without privacy, so that they could be easily monitored by their supervisors in front of them. Although the individual gained more privacy as they moved up the corporate hierarchy, the workspaces were still generally characterised by dull colours and heavy, standardised furniture (Lange 2002, Marberry 1994, Pelegrin-Genel 1996, Saval 2014).

These homogenous, unstylised organisations of the work environment were described as inhumane and productive of standardised organisation-men - a critique especially resonant due to the reviled figure of the conformist in the immediate postwar years. As Turner (2013) points out, the postwar period was generally characterised by a fear of the psychologically defective "authoritarian personality", a personality type that was dependent, irrational, and susceptible to propaganda. On the corporate front, organisations were criticised for promoting such personalities through an organisational culture that stressed deference and hierarchy. Writers like Charles Wright Mills (1953), William Whyte (1956) and David Riesman and his colleagues (1950 [2001]) accused corporations for stymieing the individualities of workers so as to secure the yes-men that would soothe the egos of those in power.

The pre-war office with its repeating rows of identical desks and chairs, depicted in films like The Apartment, became emblematic of this standardised, conformist corporate culture. The unstylised, uniform furniture and layout supported the belief that corporate culture required individuals to sacrifice their identities in order to do well. Mills $(1953,197)$ made just such a comparison, complaining that the standardised layout of offices symbolised a process where white-collared workers were increasingly being treated like machines. "The physical layout and appearance of the office becomes more factory-like", he writes, and "the employee group is transformed into a uniform mass in a soundless place".

Although Mills and many of his contemporaries were addressing the middle-class, the pre-war office also stood as a symbol of classed oppression. The large migration of American workers from factories to clerical work in the twentieth century allowed clerical staff to be seen as the new working-class. Correspondingly, the adaption of Taylorist principles to the office is read as a means of extending the alienation of workers from factories to offices (Braverman 1998 [1974]). Critically reading 
Leffingwell's relentless breakdown and optimisation of the components of the office from space to desks to pen nibs - for the purpose of efficacy, Braverman (Ibid., 214) argues that the design of the pre-war office "shackles the clerical worker as the factory worker is shackled - by placing everything within easy reach so that the clerk not only need not, but dare not, be too long away from the desk."

It is within this complex milieu of reactions against working-class discipline and middle-class conformity that Knoll and Propst came up with 'humane' designs that hoped to challenge this dominant aesthetic. They believed that spaces that engaged the senses and the mind could reinvent the psychological qualities of the worker, and cultivate a pleasure to work that would free workers from the need for constant supervision. Similar to Turner's $(2013,3)$ "democratic surrounds" - the multi-screen, multi-sound environments which encouraged individuals to choose, interpret, and integrate visual and aural stimuli so as to develop a holistic personality - Knoll and Propst believed that the sensate environments of the office could develop a new model of the office worker: workers who were more intelligent, creative, self-assured, and capable of working independently. Official materials introducing Propst's designs, for instance, related the "unresponsive environment" of the pre-war office to the "alienated, dehumanized" worker. Changing the environment, they offered, could stimulate the expression of worker's individuality and aid in the enjoyment of work, granting "a sense of personal accomplishment, a sense of possession, and of being involved with others" (Miller 1975, 14).

The ideological impetus for the transformation of offices became more urgent as information work grew in prominence. Although information work had gradually grown in significance from the late nineteenth century, its growth had escalated in the midtwentieth century onwards (Chandler 2000). Almost ten million white-collar workers were added to the workforce from 1950 to 1965 , and these numbers only grew in subsequent years as information work gained prominence (Bureau of Labor Statistics, 1968).

\subsection{Modern Office Interiors, Promotion, and Affect}

However, ideological coherence cannot completely explain the change in office interiors. This essay highlights complications in these narratives by emphasising the sales techniques employed by Knoll and Propst - the showrooms, textiles, seminars, and informational materials - which were used to attract clients to their design. This aspect is crucial because, as Knoll and Propst indicate, the modern aesthetic was not immediately preferred by the public. Although the designs were functional and aesthetically innovative, corporate leaders were accustomed to pre-war designs and saw little reason to invest large sums of money to renovate their interiors.

Knoll expressed that "there were very few clients who were interested in these ideas" when she first started out - her modern aesthetic had yet to gain cultural acceptance amongst her clients (Makovsky 2001, 37). As such, both she and Propst saw a need to innovate their methods of presentation, turning to other marketing instruments to bring the sensate experiences of their design to corporate leaders' attention. The methods of marketing they employed augmented the qualities of their design, allowing bodies to experience - perhaps more than their routine use of the furniture - the idealised feeling of the modern aesthetic. Showrooms, textiles, seminars and informational materials accentuated the emotional and sensory possibilities offered in the aesthetic, and transformed the sales pitch into something experiential at a visceral and imaginary level. 
Latour's (2004) theoretical use of affect, which foregrounds the ways in which the body is a learning instrument, is useful in helping us understand this process. The body, Latour $(2004,206)$ theorises, is not a static object, but an "interface," "a dynamic trajectory by which we learn to register and become sensitive to what the world is made of." Here, Latour emphasises the body's capacity to sense and to make sense of external stimuli; he does not assume that the body comes equipped to make nuanced differentiations between sensations, but that it can be taught and trained to do so. His explanation is clarified through the example of odour kits, instruments used to teach individuals to recognise nuances in perfume. Through this equipment, bodies may learn "to be affected" by the material environments they are presented with, and become more "articulate", capable of expressing their affectedness by other sensations that were previously unfelt (Ibid., 210).

But while Latour (2004) takes a more optimistic stance to the body's capacity of learning, it is important to note that bodily awarenesses produced through technical instruments are not natural, but prescriptive. We do not neutrally apprehend the 'reality' of the world simply by sensing it. These sensations are intertwined with discourse that guide their interpretation. As Ahmed (2004) highlights, our attachment to things are built through repetitions of prescriptive affective contacts, which over time naturalise these relations as instinctive, erasing their affective histories. We may 'like' a flower, but the emotion of liking is based on a historical enactment of relationships which teaches us that the flower is to be liked (Terada 2009). Thus, if affect is an intensity of feeling, then it is possible for this intensity to be channelled as a specific emotion through engineering processes that coach us on how such intensity is to be recognised (Thrift 2004).

As example, Giedion (1948) and Crowley (1999) have questioned the consensus of positivity and pleasure around the idea of comfort. Giedion (1948) notes how the experience of comfort is subject to a range of historically contingent postures. A person using a chair must also learn to use it; they must be able to let their body sink into the chair so that an experience of comfort can be experienced. Comfort as pleasure, therefore, relies upon adjusting one's body in a particular way - which is prescriptive rather than natural, and caters to some bodies more than others (Ahmed 2004). Further, as Crowley (1999) points out, comfort has not always been seen as desirable. In the early eighteenth century, comfort was attributed to a loss of control, and primarily used to describe apparatuses sold to the infirm, a pairing that did not provide comfort with a positive valence.

The aesthetics of contemporary workplaces is often critically understood as an instrument of neo-management, a way of getting workers to internalise the aims of their bosses and shareholders in order to maximise the profit of corporations (Dale and Gibson 2007). Beautiful workplaces, for instance, can encourage workers to spend longer hours at work. Saval (2014) noted this possibility as he navigated the designed spaces of TBWAlChiatlDay, which referenced the city in which it is situated, but felt even better than that. "Few streets in Los Angeles were as walkable as the one inside the TBWAIChiatlDay warehouse", Saval comments, and remarks that with the basketball courts and free food found within, one might wonder why one would ever leave. Saval (2014) is not the only one who has expressed such concerns; others have also voiced reservations about how amenity-rich workplaces can lengthen employees' hours of work. While game rooms, coffee, and nap rooms may be enjoyable, these spaces also function as a means to tap into unpaid wage 
hours of employees, getting them to work longer hours in exchange for a having a 'cool' workplace (Dyer-Witheford and de Peuter 2006, Ross 2003).

Further, the blurring of spatial boundaries between work and non-work encourages employees to identity more closely with organisations, and gets them to channel a larger aspect of their lives and energies - their relationships, affects, and creativity for the purposes of corporate gain (Lange 2012). As Dale and Gibson (2007) argue, the pleasurable office fulfils a dream of management consultants everywhere: it materialises the pleasurable aspects of capitalism for workers, allowing corporations to extract surplus value from them not just in the workplace but also in the spheres outside the workplace. This is especially the case because value is increasingly dependent on the monetisation of cognitive skills and affect in the broader social milieu (Morini 2007). And this process impoverishes workers as it benefits corporations. Berardi (2009) notes that affective investments into work are cyclical and self-perpetuating. As we put our energies and relationships into work, we lose sight of other pleasurable possibilities to life. This narrows the horizons of our desire, returning us to corporations and work for a sense of identity and worth.

To describe workplaces as such is not to deny possibilities of resistance or appropriation by lay workers (Warren 2002). But my interest here is to examine an earlier historical period where these relationships were yet to be normalised. A study of the promotional efforts of Knoll and Propst provides insight into the social creation of space, or the "associated images and symbols" that were necessary to make the idea of a pleasurable office desirable, understood and perceived as commonsense (Lefebvre 1991 [1974], 39). Showrooms, textiles, seminars, and informational materials can be understood as the apparatuses that made people "articulate" how good office work could feel, and how such pleasures relate to the efficiency and potentials of workers (Latour 2014, 210). The politics behind this process are the subject of the analyses to proceed.

\section{Florence Knoll: Intimacy and Fantasy}

Florence Schust (later Florence Knoll) began her career as an interior designer in the architectural firm Harrison and Abramovitz. In 1943, she left the company to assist Hans Knoll with his furniture business. They married in 1946. From 1943 to 1965, Knoll headed the Knoll Planning Unit, a section of the Knoll Associates which specialized in consultancy and design. Through the Knoll Planning Unit, Florence Knoll pioneered the profession of the interior designer, where she would work together with a team of designers to produce interior designs for the offices of her clients. By her retirement in 1965, she had made Knoll Associates one of the most influential interior design firms in the United States, leaving behind a legacy of seven Knoll showrooms, 70 projects, and a lasting imprint of the modern aesthetic in interiors (Tigerman 2007).

Influenced by the Bauhaus aesthetic, Knoll's notions of design differed greatly from the dated ideas of her corporate clients, and even those held by some architects during that time. Although Knoll would eventually be a success and "a symbol of the modern movement" (Interiors 1957, 58), her ideas were, at the onset, too radical for her contemporaries. To transform opinions about modern office interiors, Knoll had to "battle the prejudice against contemporary design", which relied heavily on the showrooms and textiles she produced (Giovannini 1983).

\subsection{Showrooms}


Contracts in the early years of the Knoll Planning Unit were slow in coming, so from 1943-51, Knoll invested most of her time and creativity into the design of showrooms. She expressed that "[the showrooms] were important because we had to do a lot of convincing...[Clients] thought they had to have traditional furniture from Grand Rapids. These showrooms were what really convinced them" (Makovsky 2001, 37).

The showrooms that Knoll created achieved their persuasive power through features that would inspire and intrigue the onlooker. As the Chicago Daily Tribune noted, these showrooms were not simply spaces where furniture was sold; they were not "a stockroom where architects and decorators merely inspect merchandise and place orders" but "a suite of tastefully furnished rooms" (Barry 1949). In this space, Knoll focused on the "integrated whole" of the aesthetic experience: she considered the architecture of the space, its walls, columns, and ceilings, and thought about how furniture, and colours could best be presented within its limits (Freeman 1957, 45). Since the showrooms were designed specifically to "win clients over to contemporary design", Knoll understood that they could not just be a collection of rooms, even nicely designed, that incorporated the expected features of a good office - rather, in order to convey a fantasy which would affect their clients and leave an impression in their minds, Knoll often built spaces that were more dramatic than the interiors of typical offices. Indeed, despite the company's specialisation in office interiors, most of Knoll showrooms displayed living-room and lounge arrangements rather than office models (Smithsonian Archives of American Art 2015)

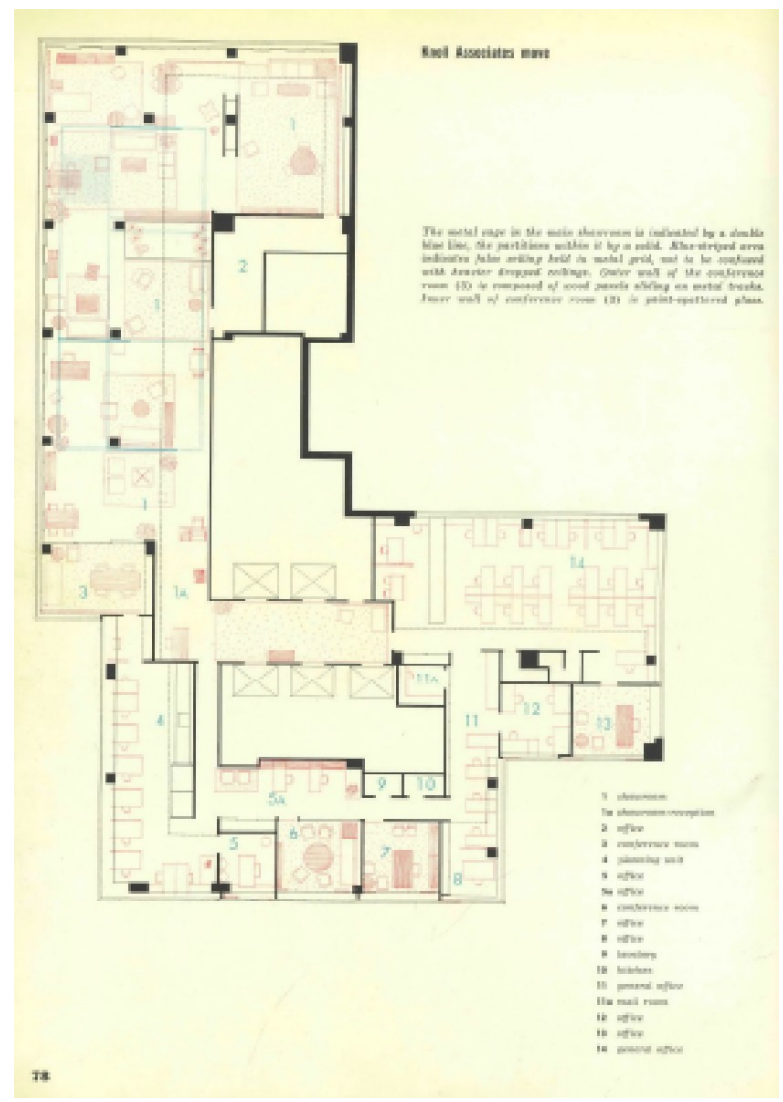

Figure 1: Floor plan of Knoll's New York showroom at 575 Madison Avenue (Interiors 1961, 78) 
This paradox can be observed from a layout map of one of Knoll's early works, her second New York showroom at 575 Madison Avenue (Figure 1). In that showroom, the rooms with the strongest statements, referencing living rooms and lounge arrangements with artfully placed sculptural furniture, exotic colours, and luxurious rugs and upholstery, were located close to the entrance. Only towards its end would one see models of office interiors. Although these offices were designed thoughtfully - L-shaped desks were placed efficiently to maximise space, low partitions were included to provide workers with privacy, and an acoustic ceiling was installed to muffle sound - it was clear that Knoll's corporate clients were meant to be most affected by the rooms that came before.

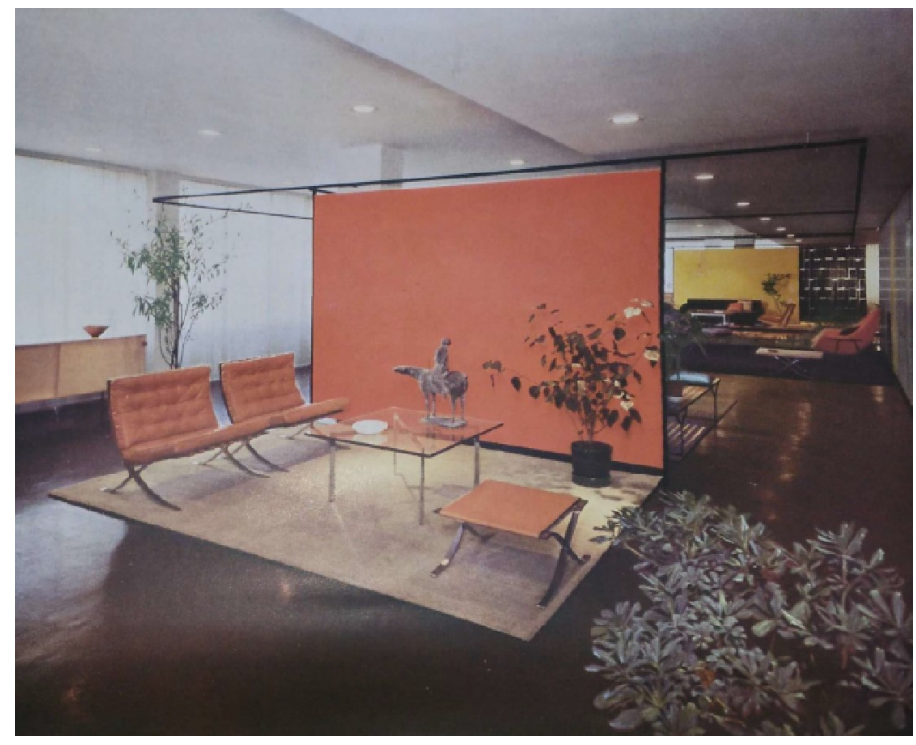

Figure 2: Entrance to the 575 Madison Avenue Knoll showroom (Architectural Review 1951, 384)

The first room sets the tone for the experience of the showroom. Instead of seeing furniture of different types clustered together, visitors were presented with a spacious scene of two orange, sculptural modern leather Barcelona chairs resting on a cream wool rug, with a Marino Marini equestrian statue placed before them (Figure 2). The unusual showroom setting conveyed a feeling of luxury, intimacy, and comfort. As visitors wandered further in, they could observe other graphic pieces of furniture, like Eero Saarinen's Grasshopper and Womb chairs, which had fanciful sculptural shapes more suited for display than use in offices. One particular room, which was photographed extensively by trade journals, even sported an artificial pool topped with lily pads (Architectural Review 1951). A black and white marble bench topped with foam seating pads was placed next to it, inviting visitors to sit and admire the setting. The easy, comfortable scene was also exciting and delightful: it proved an intriguing experience to see an artificial pool in a furniture showroom, high on the fourteenth floor of an office building.

The visuality of customers' experience was carefully calibrated within the entire space. Architectural flaws in the showrooms were diligently masked. For instance, thin black metal tubes running just below the ceiling tricked the eye into thinking that the ceiling was higher than it actually was. Attached to these tubes were movable partitions which minimised the view of the building's pillars. Floor-to-ceiling opaque panels were also used as windows to diffuse soft light into the room, and to hide 
unsightly views of radiators and sills. And if the sights were yet insufficient to convey the desired delight, Knoll topped it off with a regular inhabitant of the showrooms: Cartree, a shaggy-haired English sheepdog (Warren 1950). Often photographed lolling about, Cartree contributed towards the production of a playful, intimate mood.

\subsection{Textiles}

Textiles were another important factor in shaping the fantasy of the showrooms, enlivening them with colours, textures and movement. The textile division was founded in 1947, when Knoll felt that the textiles available in the market were either too drab or fancy for her designs (Ward 2011). Knoll's attention to textile was unusual at that time because most furniture makers were more concerned with the sculpture of their furniture pieces, often treating the upholstery as an afterthought. The upholstered materials, coloured red or cobalt blue, sometimes in stripes or peacock or persimmon patterns, and accented against white and beige backgrounds, clearly set Knoll's designs apart from the pale green, grey and brown colours of the day. Since colours were a major aspect of the Knoll brand, Eszter Haraszty, who was appointed as the head of the textile division, was also encouraged to experiment in producing them. Some of her pioneering innovations with colour, like fabrics in orange with shocking pink, were not the most saleable, but they received attention from the media for their novelty (Ibid.). In this sense, as with the showrooms, Knoll had prioritised the creation of affective materials over their immediate use value.

Knoll thought carefully about the ways in which a textile's texture and colour could best be brought to the viewers' attention. Instead of having fabrics on panels hinged to walls as was commonly done, Knoll made fabrics into centrepieces, arranging them in eye-catching formations like the petals of a flower (Dedece Blog 2011). The fabrics were also draped excessively in a manner akin to window curtains, inviting sight and touch. The light, spare, 'fishnet' textile was often placed against windows to produce movement. When this was done in the Boston showrooms, the Daily Boston Globe $(1950,11)$ wrote "The fishnet curtains which stirred gently in the May breeze and let in great drifts of sunlight brought many questions...And the fabrics which were hung against the walls like curtains had many a visitor fingering them in record time. There was spun glass fabric, which is faintly iridescent".

Such thoughtfulness directed towards touch and sight can also be observed at a travelling textile exhibition of the time, organised by the Smithsonian Institution. As Interiors (1952, 112) noted, the exhibit was not "a mere surface display, or even a stage production". Instead, Knoll envisioned it as a maze-like enclosure of fabrics that visitors could walk through and encounter closely. The exhibit was built with aluminium tubes, divided into multiple panels which provided a structure allowing fabrics to be placed in any direction, creating a path for visitors to stroll through. The individual panels were decorated with textiles cut into patterns of triangles, circles and squares and stretched out to showcase their textures and designs. Light fixtures, strategically hung by the beams, highlighted the details of these fabrics. As the visitor wandered deeper into the exhibit, more panels of fabric would surround them, accumulating to the point where the individual would be swamped by a kaleidoscope of colours, shapes, and textures (Interiors 1952). 


\subsection{Middle-Class Intimacies and Exclusions}

Many who encountered Knoll's showrooms and textiles were affected by its environments. Richard Schultz, a designer who worked with Knoll in the fifties, remarked that "you could walk into a Knoll showroom and see how the furniture worked... you got the sense instantly, 'This is something else."' A close client of Knoll's, CBS's President Frank Stanton, experienced the same awe: "I have a clear recollection of the opening of the showroom at 575 Madison Avenue. It was dramatic" (Hofstra 2008, 61). Knoll understood that the affective qualities of materials did not just reside within their inherent property, but had to be carefully brought out through the technical environment within which they were placed. Furniture pieces and fabrics were stretched, cut into fanciful shapes, strategically placed alongside ornaments and so on.

The goal here was to transform how people thought about the office. Talking about fabrics, for instance, Knoll explained that the displays were never meant to be "serious art". There was no essential meaning for viewers to grasp. Knoll had meant for the fabrics to "stimulate the imagination", getting people to encounter "the amazing range of possibilities in our related or totally unrelated colours by combining them in surprising ways" (New York Times 1962, 51).

The showrooms and textiles served as a means to awaken potential customers to the sensory possibilities of their workplaces - an aspect that was undeveloped in the pre-war designs they were accustomed to. Or, using Latour's (2004) terminology, we may say that visitors to Knoll showrooms were learning to become more affected by their workplace. As the public encountered the showrooms and textiles, they became aware of new possibilities for an office in colours, furniture, and features. They were coming to understand their office as a place for pleasure, and becoming "articulate" in expressing why colours, shapes, and materials could improve their psychological capacities for cognitive labour.

In the process, individuals were able to re-evaluate their conception of an information worker. As Thrift (2008) explains, glamour and charm can function not only to produce subjects but also to create the material world that makes certain subjects thinkable and sensible. Modern designs, which were innovative, expressive, and intimate - so different from what was found in the pre-war office - suggested an entirely different personhood. Unlike the bureaucratic, conformist yes-man who inhabited the pre-war office, the person who worked in this space was imagined to be intelligent, self-assured and creative, possessing the idealised psychological states of American individualism. Pleasurable work environments thus became recognised as spaces for self-transformation, spaces where people could imagine themselves gaining the valued traits of an information worker.

But a question remains: who is this idealised environment designed for? In striving to achieve an affective impact, Knoll had relied especially on spaces designed for those of middle and higher corporate hierarchies. Her privileging lounge and living room arrangements over standard office spaces in the showrooms indicates this. The spaces prominently displayed, and recognised to be affective, were the spaces inhabited by the management. The common workspaces were placed in the recesses of showrooms, or even not shown at all. In this sense, the feeling of awe related by onlookers was envisioned for a very specific group of workers. It was catered not toward the masses of information workers - secretaries, typists, routine clerical staff - but toward the elite classes of managers and executives who would reside in Knoll's spacious lounges and office/home hybrids. 
This is not to say that working-class information workers were not beneficiaries of Knoll's design. The conditions of work did improve for workers as the workplace itself changed - many received bigger desks that suited their work, for instance - but the hierarchised allocation of aesthetics ensured that pleasurable offices remained a symbol of status, and thus an element of desire for information workers. Pleasure was a perk for the upwardly mobile, for those who worked harder, longer hours.

This designed middle-class ambiance had the effect of working against the political solidarity required of the working-class. In one aspect, the fantasy of office related to the fantasy of meritocracy. Closeness to beautiful offices amplified the belief that such pleasures could be available to all through hard work, directing desire away from political solidarity and towards the fantasy of upward class mobility. In another aspect, the comforts of the office also divided the working class along the lines of white- and blue-collar work. Middle-class ambiance provided even lowranking information jobs with a degree of middle-class respectability, causing its workers to identify with the middle-class rather than blue-collar counterparts. This shift had the effect of segregating the working-class, making unionisation more complicated and difficult (Saval 2014).

Knoll's failure to acknowledge the politics behind information work meant that she had built the office around middle-class norms. This is not to say that she had no positive impact: as one of the few influential women designers of the time, Knoll had not only become a role model for other female designers, she had also brought some degree of public attention to the commonly devalued use and artistic production of textiles, a gendered craft that was primarily practiced by women, and in that process, created middle-class jobs for some women (Ward 2011). Yet the gains in this process were also limited. Instating a fantasy about how information work felt, Knoll's design had become a material precursor for how work was to be understood: namely, that pleasure was compatible with work, and that workers should strive to align their desires with their career so that they might gain the psychologies to achieve success in their careers and become upwardly mobile.

\section{Robert Propst: Scientific Humanism and Flexibilisation}

While Robert Propst's approach to design differed from Knoll's, he too was charged with changing the public's opinion about modern office interiors. Propst, an inventor, was hired by the CEO of Herman Miller, D.J. De Pree, in 1960. Although initially directed to diversify the company's product offerings, Propst was eventually led to examine furniture - the core of the Herman Miller business (Haigh 2012). Collaborating with architect George Nelson, he produced the Action Office I in 1964, and Action Office $/ /$ in 1968, pieces that would mark the next stage of modernist office designs (Figure 3). The Action Office, with its moveable partitions and modular workstations, represent the early forms of the office cubicles we know today. 


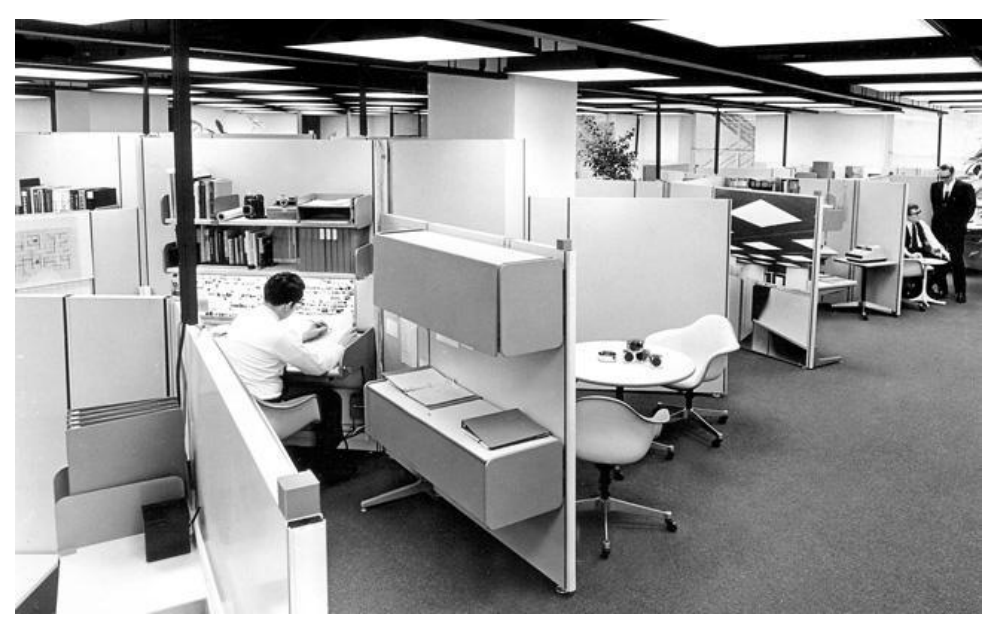

Figure 3: Action office // fully set up with partitions, shelves, and bins (Metropolis, 2013)

Unlike Knoll, who focused on aesthetic purity, Propst's ideas on office interiors were rooted in public discourse. He designed the Action Office lines because he felt that pre-war offices were both dehumanising and non-functional (Propst 1986). Influenced by the works of other intellectuals, Propst developed a framework that attended to the bodily experiences that influenced people's effectiveness in work (Caplan 1976). Some of these thought processes were apparent in the Action Office I. The Action Office I included a variety of standing and sitting arrangements to encourage movement and mental alertness amongst workers. Display areas were included so that workers could easily see and thus be reminded of what they needed to do (Black, Roark and Schwartz 1986).

But the Action Office I did not achieve commercial success despite these innovations. The failure may be partly attributed to the cost and design: the Action Office was expensive, and furniture pieces heavy (Franz 2008). But Propst also faced the same challenge that Knoll did. The public were unaccustomed to the Action Office's look and use, and though Propst did try to explain the scientific thought behind his design, his focus on the design's functionality failed to emotionally engage his potential consumers.

\subsection{Seminars}

To understand the success of the Action Office II, it is necessary to turn to the promotional techniques employed by Herman Miller and Propst. Hugh De Pree was personally invested in the second version of the action office, seeing it as a direct competitor to another popular movement in office interiors - open landscaping - an office layout heralding from Europe that had much of the same design sensibilities. Sensing both a threat and an opportunity, he set up a four-man task force to find a way to sell the Action Office II, eventually leading Joe Schwartz to be appointed as the marketing leader for the product (De Pree 1986). Schwartz understood that while this product was innovative, there was no good reason for corporate clients to change their desks which had served them well. For the Action Office // to sell, users themselves had to recognise a problem in their work environments.

Here, Schwartz's marketing strategy dovetailed with Propst's scientific approach to design. Having seen the failure in selling the Action Office I, it was decided that the Action Office II should be marketed with presentations that felt more like "genuine information rather than sales propaganda" (Caplan 1976, 94). To do this, Schwartz 
organized a closed-door three day "educational seminar", inviting only an attendance of a close-knit group of customers, architects and designers. The seminar, first organised at the Union Bank Building in Grand Rapids, combined a classroom and a sales pitch. It began with a series of topical presentations with titles like "Facilities Change in the Dynamic Corporation", "Economics of Open-Plan Architecture", and "Acoustics in the Open-Plan Environment", where participants heard from the staff at Herman Miller and discussed their problems about office environments (Gscheidle 2008, 6).

These seminars offered the setting that was necessary for the affective force of the Action Office /I to surface. Although many of the ergonomic principles behind the Action Office seem obvious today, office workers of that time were still accustomed to pre-war furniture, meaning that the considerations of the Action Office and its proper use would have seemed alien to its consumers.

The seminars gave Schwartz and his team an opportunity to address this problem. They described how each feature was to be used and why it was important. In the process, participants would learn to adjust their bodies to the Action Office, becoming more attentive to the new sensations the product offered, and learn how to interpret these sensations. Presentations on the varied sitting/standing arrangements, and the mental alertness the variations offered, for instance, would have made participants more aware of how office spaces could influence their mental states. Accordingly, when using the Action Office, they would also become more cognizant of how their energy and alertness varied with their body postures.

But the seminars were not purely informational in purpose. Schwartz, who led the seminars, brought an important injection of charisma and energy, turning the seminars into a "spectacular performance" (Caplan 1976, 94). This was especially evident in the way that the Action Office was revealed. Bryan Dozeman $(2006,29)$, a Herman Miller salesperson at the seminar, writes that the Action Office was carefully presented as an exciting "demonstration": "We would assemble a small 6x4-foot workstation in front of the audience. We took one component like a divider panel and pointed out its unique design... While we were talking about it, we would actually build a workstation...And if there weren't enough, we would rearrange it." Piece by piece, bit by bit, the Action Office was assembled, transforming from panels, screws, and boards, to a fully functional workstation. This demonstration combined showmanship with engineering, science with enchantment. Audiences, Dozeman $(2006,29)$ notes, having never saw furniture designed with such a capability before, "would be sitting at the edges of their seat", spellbound by how the small components could, in a relatively short period of time, be transformed into an entire workstation with shelves, bins, desks, and partitions.

The seminars, therefore, were not only of pedagogical value, teaching users to anticipate the sensations that the Action Office could offer: the live assembly contributed to its allure. This combination made the Action Office "come alive", infusing it with the elements that sparked desire from participants (Dozeman 2006, 28). The seminars were, in fact, so successful that they developed into a travelling road show, which brought the Action Office to the attention of hundreds of thousands across the nation (Lofton 2014).

\subsection{Informational Materials}

Through these seminars, Propst concluded that the Action Office was an "information product" that needed supplements of "books, publications, audio-visual materials, 
conferences" for proper use (Caplan 1976, 77). Put in other words, an "information product" meant that the affective quality of the Action Office was not something that could be immediately grasped, but would require education before its effect on the body could properly appear. By addressing sensation directly, Propst also targeted the imagination, encouraging readers to fantasise how work could be experienced in this "mind-oriented living space" (Propst 1986, 19).

On one level, Propst achieved this by elaborating on the research process behind the Action Office's designs. A ten-page survey, and observations at the Herman Miller experimental lab, for instance, were used as evidence of the scientific thinking behind his process of design (Abercrombie 2000). But the scientific discourse was also presented in a way that felt exciting. A booklet written by Propst which was distributed within the seminars helps illustrate this point. As Lofton $(2014,151)$ observes, the seventy-one-page booklet reads like a manifesto with "revolutionary imperatives". In the opening pages, Propst $(1986,12)$ states, "Undeniably we are already deeply involved with a new state of reality, a new iron mistress, the exponential change in the rate of change". "The office", he continues, "must now obey the dynamic new factors this imposes", and the innovative qualities of the Action Office was geared to meet these new needs.

The images used in the booklet aestheticise the innovative qualities that the Action Office purported to offer. Photographs, drawings, and graphic representation saturate almost every page of the booklet, many directed towards revealing the hidden, routinely ignored effects of the office. A section on the relationship between furniture and conversation uses a mix of text and photographs showing various sitting and standing positions. Text placed next to each photo carefully explains how even ordinary objects, like the shapes of tables, clutter on desks, and placement of furniture, could influence the ease of conversation. A seeming ordinary photograph of a group of executives is accompanied with the following text: "This requirement [the meeting] strongly favors roundish tops because they encourage free adjustment or proximity...Ninety degree location, the most natural of all conversational positions, encourages exchange. Side by side positing allows joint viewing of papers or objects intelligibly" (Propst 1986, 55). Propst brought a different perspective to seemingly ordinary accounts of office life.

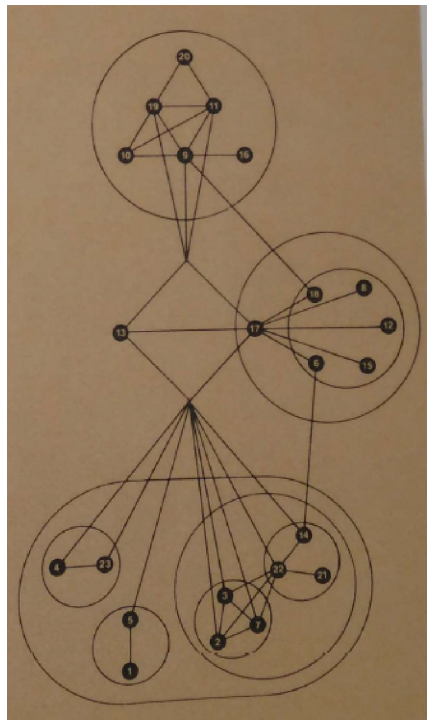

Figure 4: "Communication interaction analysis” (Propst 1986) 
Abstracted representations of information also provide the Action Office with an aura of scientific expertise. For instance, to make optimal layouts for the Action Office, Propst recommends rendering information on the communication patterns of the office into "a graphic representation of the total organization" $(1986,37)$. The resulting image shows invisible communication patterns distilled into a network of geometric lines that connect individuals and groups (Figure 4). In another instance, Propst (1986) recommends a facility planner to simulate an office layout through computer software. The image that accompanies the recommendation depicts a computer screen with an abstracted representation of the Action Office. Eighteen different components are listed on the right toolbar, and manipulative options to add, abstract, and rotate are found on the left. This use of the computer, which was uncommon when The Office booklet was circulated, added to the idea that the Action Office was breaking new frontiers.

The language and images used in The Office showed that the 'intelligent' design of the Action Office was not only narrated, but also represented aesthetically through visuals. Photographs illustrate the invisible impact of furniture objects; abstracted graphics and images of computer screens give the Action Office an enticing scientific, futuristic aura. On the one hand, the discourse here was rational and scientific, offering a plenitude of reasons why the Action Office was cutting-edge in thought. On the other, the scientific rationality was merged with enchantment. The media latched on to these new ideas. The Guardian likened the Action Office to the space program, calling it "an exciting, almost space-age interior quite unlike the sombre and characterless offices provided by so many architects today" (Carr 1973, 15). And the nature of these spaces ensured that those who worked in these offices were, as The Washington Post asserted, considered to be "well-rounded, at ease sort of [people]": "people who aren't sure of themselves" would prefer period design, as "antiques give an instant sense of status" (Wagner 1970).

\subsection{Information, Efficiency, and Flexibilisation}

The use of seminars and informational materials provided the public with a different means of understanding the material environment required for information work. But its design and the underlying rationale of efficiency also contributed to something else: a tendency to think of people in terms of their capacity to provide and require information. As Halpern (2014) remarks, the postwar period in America is marked by the production of a new visuality of data, where scientists and artists collaborated to produce actionable visualisations of patterns and relationships that lie outside our sensory recognition. In Propst's design, this related to the ideas of information and communication. Here, workers are likened to the blips on his "communication interaction analysis" charts - nodes meant to be reassigned and moved around to make the best use of space. This actionable quality to Propst's aestheticised and visualised ideas of information, therefore, enable corporate leaders to think through the logics of decentralised, networked capitalism. Likening workers to informationprocessing materials allowed them to be flexibly adjusted for the purposes of efficiency and corporate gain (Liu 2004).

This basis led the Action Office to develop in two different directions. One familiar development is the cubicle, the small box known for its dehumanising qualities. In an interview, Propst defended the Action Office, arguing that its misuse happened because "not all organizations are intelligent and progressive" and that many organisations are "run by crass people who can take the same kind of equipment and 
create hellholes" (Abraham 1998). Propst blames unenlightened corporate leaders for repurposing his panels as cages for workers. But, as for Knoll, this development was also related to his over-confidence in design. As his colleague George Nelson had anticipated, if people were thought of in terms of efficiency, what would prevent corporations from squeezing workers into tiny spaces (Saval 2014)?

Perhaps Propst had trusted too much in his middle-class idea of information workers, workers who are valued for their cognitive capacity to collaborate and to work in teams. Not all workers are prized in the same way; much of information work is routine and does not require the same degree of creativity, communicativeness, and team-work that Propst envisions in a middle-class information worker. His idea of an autonomous worker, a worker who is free to transform her surroundings in the company to express her identity (Abraham 1998) was in itself based on a managerial fantasy: a fantasy that corporations truly cared for the welfare of their employees (Fleming 2015).

Such a fantasy can be observed in another direction which the Action Office had developed: the dehierarchialised open office, a layout where workers are encouraged to remain constantly mobile and untethered to a desk. Here, fluidity is deemed to be a generator of profit: it facilitates 'serendipitous connections' and 'synergies' between employees, and helps organisations acquire the innovative, 'cutting edge' qualities demanded of contemporary capitalism. Like blimps of information sponges whose capacity for value relates to the degree of communicativeness, workers here are encouraged to communicate endlessly so that they might come up with ever more innovative and creative ideas for their companies (Lange 2012). As Sheridan (2015) explains in Joy, Inc., one of the important outcomes of the open office was that it produced a culture of constant learning. Taking his company, Menlo Innovations, as an example, he explains that the removal of boundaries allowed workers to offer input into each other's problems, and to constantly be energised by an electric environment swamped by noise.

Such noisy workspaces, flooded with light, mobile furniture, and playful trinkets, according to Sheridan (2015), has enabled Menlo Innovations to become one of the happiest companies in the world. This relates to a utopic conception of information work, workers who can find pleasure in communicating, and who are autonomous, mobile, and able to express their own individuality in the workplace. But this freedom from isolation also produces another kind of alienation. Inasmuch as the openness allows the sounds of laughter to drift from one table to another, it also enables managers and colleagues to easily identify "stragglers," people who fail to communicate enough or offer ideas of sufficient quality (Ibid.). The 'always-on' culture, in other words, involves a coercive dimension of surveillance, where workers are evaluated for their capacities to thrive in a highly communicative environment. Though different from the cubicle, the pleasurable open office is also built according to the dictates of efficiency: those who do not meet the standards of communicative value are thrown out.

The underlying connections between cubicles and open offices indicate how Propst's conception of the Action Office continued the underlying penchant for efficiency, even as it disavowed the previous models of Taylorist workspaces. The fantasy of mobility, and the pleasures afforded by an 'intelligent' workplace that can allow you to work at your best, is supported through the same definition of 'best' - the capacity for workers to produce value for the company. Thus, the Action Office, while radical in design, was ideologically conservative, continuing the objective of capitalism to achieve managerial control. 


\section{Conclusion}

The tech giant Google, a company renowned for its beautiful, innovative office designs, writes the following in its profile on "our culture": "It's really the people that make Google the kind of company it is... we hail from all walks of life... And when not at work, Googlers pursue interests ranging from cycling to beekeeping, from frisbee to foxtrot" (Google 2015). Yet images presented under this statement showed few Google workers. Instead, we are offered a series of photos showcasing the Google offices around the world. Two egg-shaped enclosures with a toy crocodile nested in between was represented for the Zurich branch. In London, the lobby is transformed into an artificial park with sundeck lounge chairs. And in Sydney, the reception desk stands in front of an artificial jungle. Suggested in this layout is the notion that spaces can better represent the subjectivities of the worker than people themselves can.

But at recent conference for coworking space operators I attended, I also heard talks that expressed how spaces can also transform the subjectivity of the worker. Several keynote speakers discuss extensively the importance of the sensory environments in the workplace, describing a myriad of factors that could influence the condition of work - traditional elements like sunlight, but also the type of music played (upbeat, slow, ambient), the taste of drinking water offered (plain, sparkling, infused), and the smells of rooms (calming, bright, appetising). These, they assure their listeners, have an impact on how happy workers felt, and the personalities they would exhibit. To ensure the authentic, productive, and delightful workers, it was essential to monitor the sensorium of the office.

And it is this imagined sensate experience of these offices that draws our attachments to a culture of work. Fewer people, for instance, might know about how much Google employees are paid than about the offices they work in. The emphasis on aesthetics in a precarious economy can be read as a means of re-enchanting our relationships with work (Bennett 2001). Such emphasis serves to direct attention away from the structural conditions of labour, towards that of a vague hopefulness produced through the aesthetics of space (Kuehn and Corrigan 2013).

This relationship between workspace, sensation and subjectivity can be traced back to the turn of the mid-twentieth century, in the promotional techniques used by Knoll and Propst. A straightforward reading of office spaces and aesthetics would be that office were beautified due to the improvements in design - that 'better' and more 'humane' modern design took over simply because it was more progressive. It is crucial to remember, however, that Knoll and Propst had focused on promotion in reaction to an initial lack of interest in their ideas. Corporate leaders were unused to modern designs and unwilling to invest large sums of money to change their interiors. Showrooms, textiles, seminars, and informational materials were explicitly employed to convince clients that this money was well spent.

By relying on the techniques of promotion, Knoll and Propst constructed a fantasy of how the modern aesthetic could revolutionise how information work felt. These instruments substantiated the affective quality of the office, teaching workers to anticipate the sensations that the office could trigger (Latour 2004), and tied these pleasurable experiences to the transformation of the self. As precursor to the discourse on corporate interiors today, they highlight how the sensorium can directly impact the subjectivities of workers.

And in focusing so much on the sensate environment, the methods of promotion blurred the subject they were talking extensively about - work - with pleasure, beauty, and an idealised future of information work. When pre-war offices were CC-BY-NC-ND: Creative Commons License, 2017. 
transformed into intimate Knoll rooms, or sophisticated, ultra-functional Action Offices, the impression of the information worker also changed. Anticipating the neoliberal qualities of the self that would become prevalent from the seventies, these environments indicated a need for workers to become more self-aware, flexible, and capable of channelling their everyday affects into their work.

Ultimately, even if Knoll and Propst had noble intentions, their emphasis in the use of design to solve social problems neglects a consideration of the operations of power. By problematising work in terms of its emotional encounter, they had introduced values that supported the interests of business. Those working in beautiful offices may be encouraged to work overtime, treating their workplaces like their homes (Ross 2003). Those working in cubicles might identify their unhappiness as being about space rather than about class structure (Saval 2014). And the normalised desire for sophisticated offices may distract us from asking important questions regarding what we want from work and how those desires come about.

This is especially crucial in the present, where there is a rise in the discourse of workspaces - where the Googleplex becomes a tourist venue and where coworking spaces are presented as a panacea to loneliness (Lange 2012). Miller, Casey, and Konchars' (2014) inverted logic of the internal and external - the therapeutic workplace and the stressful outside - might sound bewildering. Yet this has become the dominant aspect of management discourse, which constantly advises leaders to create workplaces in which people would love to stay. We need to be careful of how a middle-class aesthetic can serve as a means of distracting us from the worsening problems of labour, and the widening forms of inequality plaguing the rising cohort of freelance workers. Therapy alone cannot resolve the structural issues of capitalism.

Complicating how pleasure came to be attached to information work, and the selfhoods we deem as valuable, can help us critically untangle the root of our desires, and rethink the role work should have in our societies and lives. Perhaps the cases of Knoll and Propst can suggest a different line of possibility: what if those affecting environments were employed not to get workers to appreciate middle-class comforts and aesthetics, but to get us to gather and think in solidarity? Can we employ affective material tokens, like textiles and mobile furniture, to invoke impressions not of work, but of the "eventful", an interruption of the everyday rhythms and iconography of place (Amin 2015)? Perhaps coworking and the fear of loneliness is a sign of this potential: a desire for aesthetic iconography to draw people together.

\section{References}

Abercrombie, Stanley. 2000. Office Supplies: Evolving Furniture for the Evolving

Office. In On the Job: Design and the American Office, edited by Broikos

Chrysanthe and Albrecht Donald, 80-97. New York: Princeton Architectural Press.

Abraham, Yvonne. 1998. The Man behind the Cubicle. Metropolis: 76-115.

Agence France-Presse. 2016. 'Coworking' Grows amid Search for New Office

Lifestyle. Inquirer. Accessed May 5, 2016.

http://business.inquirer.net/207073/coworking-grows-amid-search-for-new-officelifestyle.

Ahmed, Sara. 2004. The Cultural Politics of Emotion. London: Routledge.

Amin, Ash. 2015. Animated Space. Public Culture 27 (2): 239-258.

Andrejevic, Mark. 2012. Estranged Free Labor. In Digital Labor: The Internet as

Playground and Factory, edited by Trebor Scholz, 149-64. New York: Routledge.

Architectural Review. 1951. Furniture Showrooms in New York 110: 382-87. 
Barry, Edward. 1949. Designers Put a Touch of Home into Showrooms. Chicago Daily Tribune, June 12.

Bennett, Jane. 2001. The Enchantment of Modern Life: Attachments, Crossings, and Ethics. Princeton: Princeton University Press.

Berardi, Franco Bifo. 2009. The Soul at Work: From Alienation to Autonomy. Los Angeles: Semiotext.

Black, Thomas J., Kelley S. Roark, Lisa S. Schwartz (eds.), Alton J. Penz (contributing ed.). 1986. The Changing Office Workplace. Washington, D.C.: Urban Land Institute: Building Owners and Managers Association International.

Braverman, Harry. 1998 [1974]. Labor and Monopoly Capital: The Degradation of Work in the Twentieth Century. New York: Monthly Review Press.

Caplan, Ralph. 1976. The Design of Herman Miller. New York: Whitney Library of Design.

Carr, Richard. 1973. Spacemakers. The Guardian, October 1.

Chandler, Alfred. 2000. The Information Age in Historical Perspective. In A Nation Transformed by Information: How Information Has Shaped the United States from Colonial Times to the Present, edited by Alfred Chandler and Cortada James, 338. Oxford: Oxford University Press.

Cohen, Nicole. 2012. Cultural Work as a Site of Struggle: Freelancers and Exploitation. tripleC: Communication, Capitalism \& Critique. Open Access Journal for a Global Sustainable Information Society 10(2): 141-155.

Crowley, John E. 1999. "The Sensibility of Comfort. The American Historical Review 104 (3): 749-82.

Daily Boston Globe. 1950. Well Designed Office Pieces at Home in Any Surroundings: 11.

Dale, Karen, and Burrell Gibson. 2007. The Spaces of Organisation and the Organisation of Space. London: Palgrave Macmillan.

Dedece Blog. 2011. Knoll Textiles 1945-2010 @ Bard Graduate Center, New York. Accessed May 5, 2016. http://www.dedeceblog.com/2011/06/20/knoll-textiles1945-2010-bard-centre/

De Pree, Hugh. 1986. Business as Unusual: The People and Principles at Herman Miller. Zeeland, MI: Herman Miller.

Dozeman, Bryan. 2006. Sales Insights from a Herman Miller Watercarrier. Lincoln, NE: iUniverse.

Duffy, Brooke Erin. 2015. 'Yuccies,' 'Slashies,' and the Digital Economy's Valorization of the Multi-Skilled, Always-on Creative Worker. Culture Digitally, June 18. Accessed May 5, 2016. http://culturedigitally.org/2015/06/yuccies-slashiesand-the-digital-economys-valorization-of-the-multi-skilled-always-on-creativeworker/

Dyer-Witheford, Nick, and Greig S. de Peuter. 2006. 'EA Spouse' and the Crisis of Video Game Labour: Enjoyment, Exclusion, Exploitation, and Exodus. Canadian Journal of Communication 31(3). Accessed April 4, 2017. http://www.cjconline.ca/index.php/journal/article/view/1771

Fleming, Peter. 2015. The Mythology of Work: How Capitalism Persists Despite Itself. London: Pluto Press.

Franz, David. 2008. The Moral Life of Cubicles: The Utopian Origins of Dilbert's Workspace. The New Atlantis 19: 132-39.

Freeman, William. 1957. She Designs Offices Outside In. New York Times, October 15. 
Giedion, Sigfried. 1948. Mechanization Takes Command: A Contribution to Anonymous History. New York: Oxford University Press.

Giovannini, Joseph. 1983. Florence Knoll: Form not Fashion. New York Times, April 7.

Google. 2015. Our Culture. Accessed September 7, 2015. http://www.google.com/about/company/facts/culture/

Gscheidle, Gretchen. 2008. Action Office: It Just Keeps on Going. Research/Design, 6-7.

Haigh, Gideon. 2012. The Office: A Hardworking History. Melbourne: Melbourne University Publishing.

Halpern, Orit. 2014. Beautiful Data: A History of Vision and Reason since 1945. Durham and London: Duke University Press.

Hardt, Michael and Antonio Negri. 2004. Multitude: War and Democracy in the Age of Empire. New York: Penguin Books.

Hearn, Alison. 2008. Insecure: Narratives and Economies of the Branded Self in Transformation Television. Continuum 22 (4): 495-504.

Hofstra, Philip. 2008. Florence Knoll, Design and the Modern American Office. PhD Dissertation. University of Kansas.

Horowitz, Sara, and Toni Poynter. 2012. The Freelancer's Bible: Everything You Need to Know to Have the Career of Your Dreams - On Your Terms. New York: Workman Publishing Company.

Interiors. 1951. Knoll Associates Move into the Big Time. 110: 74-83. 1952. Knoll's Kaleidoscope Knock-Down. 112-15.

1957. Florence Knoll and the Avant Garde. 116: 58-63.

Kendall, Elaine. 1964. Office Design: All the Comforts of Home. Management Review 53 (4): 59-62.

Kuehn, Kathleen, and Thomas F. Corrigan. 2013. Hope Labor: The Role of Employment Prospects in Online Social Production. The Political Economy of Communication 1 (1). Accessed September 12, 2015. http://www.polecom.org/index.php/polecom/article/view/9

Lange, Alexandra. 2002. White Collar Corbusier: From the Casier to the Cites D'affaires. Grey Room 9: 58-79.

Lange, Alexandra. 2012. The Dot-Com City: Silicon Valley Urbanism. Moscow: Strelka Press.

Latour, Bruno. 2004. How to Talk About the Body? The Normative Dimension of Science Studies. Body \& Society 10 (2-3): 205-29.

Lefebvre, Henri. 1991 [1974]. The Production of Space. Oxford: Basil Blackwell. Liu, Alan. 2004. The Laws of Cool: Knowledge Work and the Culture of Information. Chicago: University of Chicago Press.

Lofton, Kathryn. 2014. The Spirit in the Cubicle: A Religious History of the American Office. In Sensational Religion: Sensory Cultures in Material Practice, edited by Sally M. Promey, 135-58. New Haven: Yale University Press.

Makovsky, Paul. 2001. The Florence Knoll Story. Metropolis, 34-39.

Marberry, Sara. 1994. Color in the Office: Design Trends from 1950-1990 and Beyond. New York: Von Nostrand Reinhold.

Miller, Harry. 1975. Management and the Working Environment. London: Hutchinson Benham.

Miller, Rex, Mabel Casey, and Mark Konchar. 2014. Change Your Space, Change Your Culture: How Engaging Workspaces Lead to Transformation and Growth. New Jersey: John Wiley \& Sons. 
Mills, Charles Wright. 1953. White Collar: The American Middle Classes. New York: Oxford University Press.

Morini, Cristina. 2007. The Feminization of Labour in Cognitive Capitalism. Feminist Review 87: 40-59.

Murphy, Michelle. 2006. Sick Building Syndrome and the Problem of Uncertainty: Environmental Politics, Technoscience, and Women Workers. Durham and London: Duke University Press.

Neff, Gina. 2012. Venture Labor: Work and the Burden of Risk in Innovative Industries. Reprint edition. Cambridge: MIT Press.

New York Times. 1962. Art Forms Are Created Out of Fabrics and Yarn: Sculpture of Yarn: 51.

Pelegrin-Genel, Elisabeth. 1996. The Office. New York: Flammarion.

Propst, Robert. 1986. The Office: A Facility Based on Change. Michigan: Herman Miller.

Riesman, David, Nathan Glazer, and Reuel Denney. 2001. The Lonely Crowd, Revised Edition: A Study of the Changing American Character. New Haven, CT: Yale University Press.

Ross, Andrew. 2003. No Collar: The Humane Workplace and Its Hidden Costs. Philadelphia, PA: Temple University Press.

Saval, Nikil. 2014. Cubed: A Secret History of the Workplace. New York: Doubleday \& Company.

Sheridan, Richard. 2015. Joy, Inc.: How We Built a Workplace People Love. New York: Portfolio.

Smithsonian Archives of American Art. 2015. Florence Knoll Bassett Papers, 19322000. Accessed September 25, 2015. http://www.aaa.si.edu/collections/florenceknoll-bassett-papers-6312/more

Solman, Paul. 2015. Selling Office Space and Happy Hour to a Rising Economy of Freelancers. Public Broadcasting Service. Accessed April 4, 2017. http://www.pbs.org/newshour/bb/selling-office-space-happy-hour-rising-economyfreelancers/

Terada, Rei. 2009. Looking Away: Phenomenality and Dissatisfaction, Kant to Adorno. Cambridge, MA: Harvard University Press.

Thrift, Nigel. 2004. Intensities of Feeling: Towards a Spatial Politics of Affect. Geografiska Annaler: Series B, Human Geography 86 (1): 57-78.

Thrift, Nigel. 2008. The Material Practices of Glamour. Journal of Cultural Economy 1 (1): 9-23.

Tigerman, Bobbye. 2007. 'I Am Not a Decorator': Florence Knoll, the Knoll Planning Unit and the Making of the Modern Office. Journal of Design History 20 (1): 61-74.

Turner, Fred. 2013. The Democratic Surround: Multimedia and American Liberalism from World War II to the Psychedelic Sixties. Chicago: Chicago University Press.

Wagner, Ruth. 1970. Fine Design Making Business a Pleasure. The Washington Post: $\mathrm{H} 1$.

Ward, Susan. 2011 Making Knoll Textiles: Integrated Fabrics for Modern Interiors, 1945-65. In Knoll Textiles: 1945-2010, edited by Earl Martin, 102-177. New York: Simon and Schuster.

Warren, Margaret. 1950. Top-Flight Rating Comes in 10 Years to Home-Furnishing Team. The Christian Science Monitor, January 25. 
Warren, Samantha. 2002. 'Show Me How it Feels to Work Here': Using Photography to Research Organizational Aesthetics. Ephemera: Critical dialogues on organization 2 (3): 224-245.

Virno, Paolo. 1996. The Ambivalence of Disenchantment. In Radical Thought in Italy: A Potential Politics, edited by Paolo Virno and Michael Hardt, 12-33. Minneapolis: University of Minnesota Press.

\section{About the Author}

\section{Renyi Hong}

Renyi Hong is a doctoral student at the Annenberg School of Communication, University of Southern California. He is interested in the affective dimensions of working life, especially the ways in which the passionate engagement with work is made a part of the good life fantasy, and how these sentiments form a moral language for the contemporary changes to work culture and its practices. 